Wahana Didaktika Vol. 18 No.3 September 2020 : 306-315

\title{
TINGKAT KESEGARAN JASMANI SISWA KELAS III SD NEGERI 204 KECAMATAN KERTAPATI KOTA PALEMBANG
}

\author{
Oleh:Khemal Yanuar, Ilham Arvan Junaidi, Rury Rizhardi \\ Email : arvan_coky@yahoo.com \\ (Universitas PGRI Palembang)
}

\begin{abstract}
Abstrak
Penelitian ini dilatarbelakangi dengan belum adanya data tentang adanya tingkat kesegaran jasmani siswa di SD Negeri 204 Palembang. Tujuan dari penelitian ini untuk mengetahui Tingkat kesegaran jasmani siswa kelas III di Sekolah Dasar Negeri 204 Palembang Kecamatan Kertapati. Penelitian ini merupakan jenis penelitian kuantitatif. Dalam penelitian ini yang menjadi populasi adalah siswa kelas III SD Negeri 204 Palembang, jumlah sampel penelitan ini 53 siswa dengan menggunakan teknik random sampling. Pengumpulan data dilakukan dengan test terhadap seluruh sisiwa kelas III Sekolah Dasar Negeri 204 Palembang. Hasil penelitian ini menunjukkan bahwa tingkat kesegaran jasmani siswa kelas III Sekolah Dasar Negeri 204 Palembang tahun 2020 dengan Rata-rata 14,90 yang terletak pada interval 14-17 dilihat dari norma tes tingkat kesegaran jasmani siswa 10-12 tahun dan diketahui tingkat kesegaran jasmani siswa dalam klasifikasi sedang.
\end{abstract}

Kata Kunci : Kesegaran Jasmani, Tingkat Kesegaran Jasmani Siswa

\section{THE LEVEL OF PHYSICAL FRESHNESS OF CLASS III STUDENTS SD NEGERI 204 KECAMATAN KERTAPATI KOTA PALEMBANG}

\begin{abstract}
This research is based on the lack of data about the level of physical fitness of students at 204 Palembang Elementary School. The purpose of this study was to determine the level of physical fitness of third grade students in 204 Palembang Primary School, Kertapati District. This research is a type of quantitative research. In this study, the population was grade III 204 Palembang Elementary School students. The total sample of this research were 53 male and female students using random sampling techniques. Data collection was carried out with tests on all grade III students of 204 Palembang Primary School. The results of this study indicate that the physical fitness level of grade III Palembang 204 Elementary School students in 2020 with an average of 14.90 which is located at intervals of 14-17 seen from the test norms of students' physical fitness level of 10-12 years and known level of physical fitness of students in the medium classification.
\end{abstract}

Keywords: Physical Freshness, Student's Physical Freshness Level 


\section{A. PENDAHULUAN}

Kesegaran jasmani didefinisikan oleh beberapa organisasi sebagai suatu keadaan yang dimiliki atau dicapai seseorang dalam kaitannya dengan kemampuan untuk melakukan aktivitas fisik. Istilah kesegaran jasmani juga meliputi kemampuan untuk melakukan kegiatan atau pekerjaan sehari-hari dan adaptasi terhadap pembebanan fisik tanpa menimbulkan kelelahan berlebih dan masih mempunyai cadangan tenaga untuk menikmati waktu senggang maupun pekerjaan yang mendadak serta bebas dari penyakit.

Kesegaran jasmani sering juga disebut kebugaran jasmani atau physical fitness. Kesegaran jasmani merupakan hal yang rumit dan kompleks. Ada beberapa pendapat tentang pengertian kesegaran jasmani dari para ahli, kebugaran = kebugaran jasmani yaitu kemampuan seseorang untuk malakukan kerja sehari-hari secara efisien tanpa menimbulkan rasa lelah yang berarti sehingga masih bisa menikmati waktu luangnya. Kesegaran jasmani adalah kesanggupan dan kemampuan seseorang untuk melakukan pekerjaan dengan efisien tanpa menimbulkan kelelahan yang berarti.

Peserta didik yang mempunyai tingkat kesegaran jasmani baik dapat melaksanakan aktivitas pembelajarannya dengan lancar. Pesrta didik tidak mudah lelah sehingga mudah dalam menerima materi pembelajaran yang diberikan oleh guru. Hal ini akan memperlancar pelaksanaan proses pembelajaran di sekolah. Kesegaran jasmani dapat dimiliki oleh peserta didik dengan berbagai macam usaha. Di antaranya adalah dengan melakukan aktivitas olahraga yang teratur. Selain itu juga harus didukung dengan mengkonsumsi makanan yang bergizi untuk memenuhi kebutuhan gizi yang seimbang dalam tubuh.

Kondisi SD Negeri 204 yang berada di daerah pinggiran kota, di mana sebagian besar orang tua siswa siswi berprofesi sebagai buruh harian lepas, tukang becak dan serabutan, sehingga aktivitas siswa setelah pulang sekolah yaitu bermain game pada gadget masing-masing atau ke tempat dimana anak-anak berkumpul bermain game online. Dikarenakan orang tua siswa tidak dapat lagi mengontrol anaknya setelah pulang sekolah dikarenakan pekerjaan orang tua 
tersebut, aktivitas lain di luar sekolah adalah mengaji itupun hanya 3 kali dalam seminggu.

Hampir sepanjang waktu kehidupannya anak selalu dalam kondisi bermain. Apabila ada seorang anak yang duduk termenung tanpa melakukan apaapa dapat dipastikan bahwa anak tersebut sudah tidak dalam keadaan normal, mungkin sedang sakit fisik maupun psikis keduanya. Oleh sebab itu, dapat dikatakan bahwa permainan seusia umurnya dengan manusia, kapan dan dimana ada manusia di situ selalu ada permainan (Hermansah, 2016).

Selain itu, anak sekolah dasar pendidikan merupakan awal mula mereka mengenal lingkungan yang luas untuk belajar maupun bermain, sehingga perhatian yang khusus harus didapatkan oleh seorang anak sekolah dasar tersebut (Marjuni, Hermansah, \& Imansyah, 2020). Pada kondisi lingkungan serta faktor kecukupan gizi peserta didik di SD Negeri 204 palembang sangat mempengaruhi kondisi kesegaran jasmani mereka. Maka dari itu peneliti tertarik untuk melakukan tes kesegaran jasmani peserta didik yang berada di Kelas III dengan umur mereka yang rata-rata 8-11 tahun. Tentunya tujuan tes tingkat kesegaran jasmani ini untuk memantau dan meninjau kesehatan peserta didik secara berkala. Sehingga dapat memudahkan guru pendidikan jasmani dan kesehatan dalam memberikan porsi kegiatan pembelajaran penjaskes di sekolah sesuai dengan kondisi tingkat kesegaran jasmani peserta didik masing-masing.

Berdasarkan latar belakang di atas, maka permasalahan dalam penelitian ini dapat dirumuskan yaitu: Seberapa besar tingkat kesegaran jasmani siswa Kelas III di Sekolah Dasar Negeri 204 Palembang Kecamatan Kertapati. Penelitian ini juga bertujuan untuk mengetahui Tingkat kesegaran jasmani siswa kelas III di Sekolah Dasar Negeri 204 Palembang Kecamatan Kertapati.

\section{B. METODOLOGI PENELITIAN}

Menurut Sugiyono ( 2016:14) Metode penelitian kuantitatif adalah metode penelitian yang berlandaskan pada filsafat positivisme, digunakan untuk meneliti pada populasi dan sampel tertentu, teknik pengambilan sampel pada umumnya dilakukan secara random, penggumpulan data menggunakan instrumen penelitian, 
analisis data bersifat kuantitatif/statistik dengan tujuan untuk menguji hipotesis yang telah ditetapkan.

Dengan demikian, metode penelitian kuantitatif dapat di artikan sebagai metode yang dipergunakan untuk mencari pengaruh perlakuan tertentu terhadap yang lain dalam kondisi yang terkendali. Peneliti metode kuantitatif dikarenakan peneliti ingin mengetahui seberapa besar tingkat kesegaran jasmani siswa Kelas III Sekolah Dasar Negeri 204 Palembang, Teknik yang digunakan untuk mengumpulkan data yaitu teknik tes, pengukuran perlakuan langsung pada siswa kelas III di SDN 204 Palembang dengan menggunakan instrument tes Kebugaran Jasmani Indonesia (TKJI) kelompok anak kelas III.

\section{HASIL PENELITIAN DAN PEMBAHASAN}

Pada pelaksanaan penelitian ini menggunakan tes, berupa tes kesegaran jasmani Indonesia untuk anak umur 10-12 tahun, tes ini terdiri atas 5 (lima) jenis tes, yaitu: (1) lari 30 meter (2) tes gantung siku tekuk, (3) baring duduk 30 detik, (4) loncat tegak, (5) lari 600 meter. Deskripsi hasil tes TKJI siswa kelas III SD Negeri 204 Palembang sebagai berikut :

Tabel 4.1 Distribusi Frekuensi Tingkat Kesegaran Jasmani Indonesia Siswa Kelas III SD Negeri 204 Palembang

\begin{tabular}{|c|c|c|c|c|}
\hline No & $\begin{array}{c}\text { Jumlah } \\
\text { Nilai }\end{array}$ & Kategori & Frekuensi & $\%$ \\
\hline 1 & $22-25$ & Baik Sekali & 0 & 0 \\
\hline 2 & $18-21$ & Baik & 11 & 20.75 \\
\hline 3 & $14-17$ & Sedang & 31 & 58.49 \\
\hline 4 & $13-10$ & Kurang & 11 & 20.75 \\
\hline 5 & $9-5$ & Kurang Sekali & 0 & 0 \\
\hline \multicolumn{3}{|c|}{ Jumlah } & 53 & $100 \%$ \\
\hline
\end{tabular}

Berdasarkan tabel dan di atas menunjukan bahwa data tingkat kesegaran jasmani siswa kelas III SD Negeri 204 Palembang berada pada kategori "kurang sekali" dengan presentase sebesar 0\% (0 siswa), kategori "kurang” persentase sebesar 20,75\% (11 siswa) kategori “sedang” persentase sebesar 58,49\% (31 
siswa), kategori "baik" presentase sebesar 20,75\% (11 siswa) dan kategori "baik sekali” dengan presentase sebesar 00,00\% (0 siswa).

\section{Hasil Sprint 30}

Hasil data tes sprint 30 meter siswa kelas III SD Negeri 204 Palembang, menghasilkan seperti pada tabel di bawah ini:

\section{Tabel 4.2 Frekuensi Lari 30 Meter Siswa Kelas III SD Negeri 204 Palembang}

\begin{tabular}{|c|c|c|c|c|}
\hline No & Klarifikasi & Kategori & Frekuensi & $\%$ \\
\hline 1 & $\begin{array}{l}\text { s.d - 6,7”(Pi) } \\
\text { s.d-6,3”(Pa) }\end{array}$ & Baik Sekali & 0 & $00,00 \%$ \\
\hline 2 & $\begin{array}{l}6,8 "-7,5 "(\mathrm{Pi}) \\
6,4 "-6,9 "(\mathrm{~Pa})\end{array}$ & Baik & 11 & $20,75 \%$ \\
\hline 3 & $\begin{array}{l}7,6 "-8,3 ”(\mathrm{Pi}) \\
7,0 "-7,7 ”(\mathrm{~Pa})\end{array}$ & Sedang & 13 & $24,52 \%$ \\
\hline 4 & $\begin{array}{l}8,4 "-9,6 "(\mathrm{Pi}) \\
7,8 ”-8,8 ”(\mathrm{~Pa})\end{array}$ & Kurang & 29 & $54,71 \%$ \\
\hline 5 & $\begin{array}{l}9,7 "-\text { dst (Pi) } \\
8,9 "-\text { dst (Pa) }\end{array}$ & Kurang Sekali & 0 & $00,00 \%$ \\
\hline \multicolumn{3}{|c|}{ Jumlah } & 53 & $100 \%$ \\
\hline
\end{tabular}

Berdasarkan tabel di atas menunjukan bahwa data lari 30 meter siswa kelas III SD Negeri 204 Palembang berada pada kategori "kurang sekali“ dengan presentase sebesar $00.00 \%$ (0 siswa), kategori "kurang" presentase sebesar 54,71\% (29 Siswa), kategori "Sedang" sebesar 24,52\% (13 siswa), kategori "baik" presentase sebesar 20,75\% (11 siswa), kategori "Baik Sekali" presentase $00.00 \%$ (0 siswa), sedangkan berdasarkan nilai rata-rata yaitu 7.16, lari 30 meter Siswa Kelas III SD Negeri 204 Palembang masuk dalam kategori "Sedang“.

\section{Hasil Full Up}

Data hasil tes full up tekuk Siswa Kelas III SD Negeri 204 Palembang, menghasilkan seperti pada tabel di bawah ini:

Tabel 4.3 Distribusi Frekuensi Gantung Siku Siswa Kelas III SD Negeri 204 Palembang.

\begin{tabular}{|c|l|c|c|c|}
\hline No & \multicolumn{1}{|c|}{ Klarifikasi } & Kategori & Frekuensi & \% \\
\hline 1 & $\begin{array}{l}40 " \text { keatas" }(\mathrm{Pi}) \\
51 \text { " keatas }(\mathrm{Pa})\end{array}$ & Baik Sekali & 0 & $00,00 \%$ \\
\hline 2 & $20 "-39$ " $(\mathrm{Pi})$ & Baik & 22 & $41,50 \%$ \\
\hline
\end{tabular}


Tingkat Kesegaran Jasmani.... (Khemal Yanuar, Ilham Arvan Junaidi, Rury Rizhardi)

\begin{tabular}{|c|c|c|c|c|}
\hline No & Klarifikasi & Kategori & Frekuensi & $\%$ \\
\hline & $31 "-50 "(\mathrm{~Pa})$ & & & \\
\hline 3 & $\begin{array}{l}08 "-19 "(\mathrm{Pi}) \\
15 "-30 "(\mathrm{~Pa})\end{array}$ & Sedang & 17 & $32,07 \%$ \\
\hline 4 & $\begin{array}{l}02 "-07 "(\mathrm{Pi}) \\
05 "-14 "(\mathrm{~Pa})\end{array}$ & Kurang & 14 & $26,41 \%$ \\
\hline 5 & $\begin{array}{l}0 "-0.1 "(\mathrm{Pi}) \\
04 " \mathrm{dst}(\mathrm{Pa})\end{array}$ & $\begin{array}{c}\text { Kurang } \\
\text { Sekali }\end{array}$ & 0 & $00,00 \%$ \\
\hline \multicolumn{3}{|c|}{ Jumlah } & 53 & $100 \%$ \\
\hline
\end{tabular}

Berdasarkan tabel dan grafik di atas menunjukan bahwa data full up Siswa Kelas III SD Negeri 204 Palembang berada pada kategori "kurang sekali“ dengan presentase sebesar 00.00\% (0 siswa), kategori “ kurang “ presentase sebesar 26,41\% (14 Siswa), kategori "Sedang” sebesar 32,07 \% (17 siswa), kategori "baik" presentase sebesar 41,50 \% (22 siswa), kategori "Baik Sekali" presentase $00.00 \%$ (0 siswa), sedangkan berdasarkan nilai rata-rata yaitu 15.969, gantung siku tekuk Siswa Kelas Kelas III SD Negeri 204 Palembang masuk dalam kategori "Sedang “.

\section{Hasil Sit Up}

Hasil data Sit up Siswa Kelas III SD Negeri 204 Palembang dapat dilihat seperti pada tabel dibawah ini. Berikut hasil data baring duduk siswa kelas III SD Negeri 204 Palembang:

\section{Tabel 4.4 Distribusi Frekuensi Sit Up Siswa} Kelas III SD Negeri 204 Palembang

\begin{tabular}{|c|l|c|c|c|}
\hline No & Klarifikasi & Kategori & Frekuensi & \% \\
\hline 1 & $\begin{array}{l}20 \text { keatas }(\mathrm{Pi}) \\
23 \text { keatas }(\mathrm{Pa})\end{array}$ & $\mathrm{BS}$ & 10 & $18,86 \%$ \\
\hline 2 & $\begin{array}{l}14-19(\mathrm{Pi}) \\
18-22(\mathrm{~Pa})\end{array}$ & $\mathrm{B}$ & 12 & $22,64 \%$ \\
\hline 3 & $\begin{array}{l}07-13(\mathrm{Pi}) \\
12-17(\mathrm{~Pa})\end{array}$ & $\mathrm{S}$ & 19 & $35,84 \%$ \\
\hline 4 & $\begin{array}{l}02-06(\mathrm{Pi}) \\
04-11(\mathrm{~Pa})\end{array}$ & $\mathrm{K}$ & 12 & $22,64 \%$ \\
\hline 5 & $\begin{array}{l}0-01(\mathrm{Pi}) \\
0-03(\mathrm{~Pa})\end{array}$ & $\mathrm{KS}$ & 0 & $00,00 \%$ \\
\hline \multicolumn{5}{|c|}{ Jumlah } \\
\hline
\end{tabular}


Berdasarkan tabel di atas menunjukan bahwa data sit up siswa Kelas III SD Negeri 204 Palembang berada pada kategori "kurang sekali“ dengan presentase sebesar 00.00\% (0 siswa), kategori "kurang" presentase sebesar 22,64\% (12 Siswa), kategori "Sedang” sebesar 35,84\% (19 siswa), kategori "baik" presentase sebesar 22,64\% (12 siswa), kategori "Baik Sekali” presentase 18,86\% (10 siswa), sedangkan berdasarkan nilai rata-rata yaitu 12.594, sit up siswa Kelas III SD Negeri 204 Palembang masuk dalam kategori “ Sedang “.

\section{Hasil Vertical Jump}

Hasil data vertical jump siswa Kelas III SD Negeri 204 Palembang, menghasilkan seperti pada tabel dibawah ini :

Tabel 4.5 Distribusi Frekuensi Vertical Jump Siswa Kelas III SD Negeri 204 Palembang

\begin{tabular}{|c|c|c|c|c|}
\hline No & Klarifikasi & $\mathbf{K}$ & $\mathbf{F}$ & $\%$ \\
\hline 1 & $\begin{array}{l}42 \text { ke atas }(\mathrm{Pi}) \\
46 \text { ke atas }(\mathrm{Pa})\end{array}$ & BS & 0 & $00,00 \%$ \\
\hline 2 & $\begin{array}{l}34-41(\mathrm{Pi}) \\
38-45(\mathrm{~Pa})\end{array}$ & B & 8 & $15,09 \%$ \\
\hline 3 & $\begin{array}{l}28-33(\mathrm{Pi}) \\
31-37(\mathrm{~Pa}))\end{array}$ & S & 32 & $60,37 \%$ \\
\hline 4 & $\begin{array}{l}21-27(\mathrm{Pi}) \\
24-30(\mathrm{~Pa})\end{array}$ & $\mathrm{K}$ & 13 & $24,52 \%$ \\
\hline 5 & $\begin{array}{l}20 \text { dst }(\mathrm{Pi}) \\
23 \mathrm{dst}(\mathrm{Pa})\end{array}$ & $\mathrm{KS}$ & 0 & $00,00 \%$ \\
\hline \multicolumn{3}{|c|}{ Jumlah } & 53 & $100 \%$ \\
\hline
\end{tabular}

Berdasarkan tabel di atas menunjukan bahwa data ertical jump siswa Kelas III SD Negeri 204 Palembang berada pada kategori "kurang sekali“ dengan presentase sebesar 0,00\% (0 siswa), kategori “ kurang “ presentase sebesar 24,52\% (13 Siswa), kategori "Sedang” sebesar 60,37\% (32 siswa), kategori "baik" presentase sebesar 15,09 \% (8 siswa), kategori "Baik Sekali" presentase $00.00 \%$ (0 siswa), sedangkan berdasarkan nilai rata-rata yaitu 25,7, vertical jump siswa Kelas III SD Negeri 204 Palembang masuk dalam kategori "Sedang“.

\section{Hasil Sprint 600 meter}

Hasil data dari Sprint 600 M siswa Kelas III SD Negeri 204 Palembang, menghasilkan seperti pada tabel di bawah ini: 
Tabel 4.6 Frekuensi Sprint 600m Siswa Kelas III SD Negeri 204 Palembang

\begin{tabular}{|c|c|c|c|c|}
\hline No & Klarifikasi & $\mathbf{K}$ & $\mathbf{F}$ & $\%$ \\
\hline 1 & $\begin{array}{l}\text { s.d-2'32" }(\mathrm{Pi}) \\
\text { s.d-2'09" (Pa) }\end{array}$ & $\mathrm{BS}$ & 1 & $\begin{array}{c}1,88 \\
\%\end{array}$ \\
\hline 2 & $\begin{array}{l}\text { 2'33" - 2'54”(Pi) } \\
2^{\prime} 10^{\prime \prime}-2^{\prime} 30 \text { '(Pa) }\end{array}$ & B & 7 & $\begin{array}{c}13,20 \\
\%\end{array}$ \\
\hline 3 & $\begin{array}{l}2^{\prime} 55^{\prime \prime}-3{ }^{\prime} 28^{\prime \prime}(\mathrm{Pi}) \\
2^{\prime} 31^{\prime \prime}-2^{\prime} 45^{\prime \prime}(\mathrm{Pa})\end{array}$ & $S$ & 26 & $\begin{array}{c}49,05 \\
\%\end{array}$ \\
\hline 4 & $\begin{array}{l}\text { 3'29"' - 4'22" (Pi) } \\
\text { 2'46" - 3'44"(Pa) }\end{array}$ & K & 19 & $\begin{array}{c}35,84 \\
\%\end{array}$ \\
\hline 5 & $\begin{array}{l}4{ }^{\prime} 23^{\prime \prime}-\operatorname{dst}(\mathrm{Pi}) \\
3,45^{\prime \prime}-\mathrm{dst}(\mathrm{Pa})\end{array}$ & $\mathrm{KS}$ & 0 & $\begin{array}{c}00,00 \\
\%\end{array}$ \\
\hline \multicolumn{3}{|c|}{ Jumlah } & 53 & $100 \%$ \\
\hline
\end{tabular}

Berdasarkan table di atas menunjukan bahwa data Sprint $600 \mathrm{M}$ siswa Kelas III SD Negeri 204 Palembang berada pada kategori "kurang sekali“" dengan presentase sebesar 0,00\% (0 siswa), kategori “ kurang " presentase sebesar 35,84\% (19 Siswa), kategori "Sedang" sebesar 49,05\% (26 siswa), kategori "baik" presentase sebesar 13,20\% (7 siswa), kategori "Baik Sekali” presentase 1,88\% (1 siswa), sedangkan berdasarkan nilai rata-rata yaitu 32.8, Sprint 600 M siswa Kelas III SD Negeri 204 Palembang masuk dalam kategori “ Sedang “.

\section{PEMBAHASAN}

Pelaksanaan penelitian ini bertujuan untuk mengetahui tingkat kesegaran jasmani siswa Kelas III SD Negeri 204 Palembang Tahun 2020. Berdasarkan hasil analisis tes kesegaran jasmani menunjukan bahwa Tingkat Kesegaran Jasmani Indonesia siswa Kelas III SD Negeri 204 Palembang tahun 2020. berada pada kategori "baik sekali“" dengan presentase sebesar 0\% (0 siswa), kategori "baik" persentase sebesar 20,75\% (11 siswa) kategori "sedang" persentase sebesar 58,49\% (31 siswa), kategori "kurang" presentase sebesar 20,75\% (11 siswa) dan kategori "kurang sekali" dengan presentase sebesar 00,00 \% (0 siswa).

Kesegaran Jasmani mempunyai peranan penting dalam mengembangkan kemampuan, kesanggupan dan daya tahan diri sehingga dapat mempertinggi daya tahan diri sehingga dapat mempertinggi daya aktivitas kerja maupun belajar.Hal ini tidak terlepas dari beberapa faktor yang mempengaruhinya. Faktor-faktor 
yang dapat mempengaruhi kesegaran jasmani fisik adalah: (1) Umur, (2) jenis kelamin, (3) keturunan, (4) makanan yang dikonsumsi, (5) rokok, (6) berolahraga (Irianto, 2004:3).

Kesegaran jasmani memegang peranan yang sangat penting dalam menentukan produktivitas kinerja pada umumnya dan latihan pada khususnya. Manfaat kesegaran jasmani sangat beragam, salah satu diantaranya yaitu kesegaran bagi atlet untuk dapat meningkatkan kemauan dan kemampuan berlatih. Contoh yang dapat dilihat adalah jika kondisi fisik terganggu (sakit), peserta didik tidak mampu berkonsentrasi dalam mengikuti proses belajar mengajar dengan baik. Jika kondisi ini terus berlangsung, dapat mempengaruhi prestasi peserta didik dalam pembelajaran.

Slameto (2010:54-72) menerangkan bahwasannya salah satu faktor pendukung belajar adalah faktor kesehatan. Sehat berarti dalam kondisi baik segenap badan beserta bagian-bagiannya atau bebas dari penyakit. Kesehatan yaitu keadaan yang sehat.Kesehatan seseorang berpengaruh terhadap belajarnya. Proses belajar seseorang akan terganggu jika kesehatan seseorang terganggu, selain itu juga fungsi alat inderanya serta tubuhnya tidak bekerja secara maksimal. Oemar Hamalik (2011: 32-33) mendefinisikan bahwa faktor yang mendukung belajar terbagi menjadi beberapa macam, salah satu diantaranya adalah faktor fisiologis. Kondisi badan peserta didik yang belajar sangat berpengaruh dalam proses belajar. Badan yang lemah, lelah tidak dapat melakukan kegiatan belajar yang sempurna.

\section{SIMPULAN}

Berdasarkan data yang diperoleh dari hasil tes kesegaran jasmani indonesia pada siswa kelas III SD Negeri 204 Palembang serta hasil pembahasan dapat disimpulkan bahwa:

1. Tingkat Kesegaran Jasmani Indonesia siswa Kelas III SD Negeri 204 Palembang tahun 2020 . berada pada kategori "kurang sekali “ dengan presentase sebesar $0 \%$ (0 siswa),kategori "kurang” persentase sebesar 20,75\% (11 siswa) kategori “sedang” persentase sebesar 58,49 \% (31 
siswa), kategori "baik" presentase sebesar 20,75\% (11 siswa) dan kategori “baik sekali” dengan presentase sebesar 00,00 \% (0 siswa).

2. Faktor-faktor yang dapat mempengaruhi kesegaran jasmani fisik adalah: (1)Umur, (2) jenis kelamin,(3) keturunan,( 4 ) makanan yang dikonsumsi, (5) rokok, (6) berolahraga).

\section{DAFTAR PUSTAKA}

Hamalik, O. (2011). Proses Belajar Mengajar. Jakarta: Bumi Aksara

Hermansah, B. (2016). Pengaruh Latihan Permainan Tradisional Bentengan terhadap Sprint 50 meter pada Siswa Putra Kelas IV SD N 2 Indralaya Utara. Wahana Didaktika Jurnal Ilmu Kependidikan, 14(1), 29-43.

Irianto, Djoko Pekik. (2004). Pedoman Praktis Berolahraga Untuk Kebugaran dan Kesehatan. Yokyakarta: Andi Ofset.

Marjuni, Hermansah, B., \& Imansyah, F. (2020). Upaya Meningkatkan Kemampuan Kerjasama dalam Belajar melalui Permainan Tradisional Pesan Berantai pada Anak Kelas IV SD Negeri 02 Rantau Panjang Kabupaten Ogan Ilir. Seminar Nasional Olahraga. 2, pp. 443-452. Palembang: Pendidikan Jasmani FKIP Universitas PGRI Palembang.

Slameto. (2010). Belajar dan faktor-faktor yang Mempengaruhinya. Jakarta: PT. Rineka Cipta

Sugiyono. (2016). Metode Penelitian Kuantitatif, Kualitatif dan R\& D. Bandung: Alfabeta. 